\title{
Beta-blockers in patients with chronic obstructive disease and coexistent cardiac illnesses
}

Luis Puente-Maestu ${ }^{1,2,3^{*}}$, Luis Antonio Álvarez-Sala ${ }^{2,3,4}$ and Javier de Miguel-Díez ${ }^{1,2,3}$

\begin{abstract}
Chronic obstructive pulmonary disease is prevalent condition commonly associated with cardiovascular diseases. When both are combined the prognosis of the patient worsens. One cornerstone therapy for most cardiac diseases is beta-blockade, however concerns about its potential harmful effects on airways function often restrains their use in patients with COPD and coexistent cardiac diseases. While selective beta ${ }_{1}$ adrenergic blockers seem to have a better safety profile, other non-selective beta-blockers can be securely utilized in stable COPD patients with no or little reactivity when they are indispensable and used with caution.

Evidence provided by post hoc analysis of clinical trials and large observational studies suggests a beneficial effect of beta-blockers on mortality and exacerbations in mild to moderate COPD patients. Benefits are less obvious in severe COPD.

Studies on the actual use of beta-blockers suggest that many cardiac patients with COPD (or vice versa) who can benefit from beta-blocker utilization do not receive such medication as it is recommended in the guidelines because of die-hard, not justified in most cases, concerns on safety.
\end{abstract}

Keywords: Cardioselective, COPD exacerbations, COPD mortality, Heart failure, Coronary artery disease, Beta-blockers

\section{Introduction}

Chronic obstructive pulmonary disease (COPD) is a prevalent condition affecting 6-10\% of the general population and $11-18 \%$ of the individuals older than 65 years [1]. Many patients with COPD have concomitant heart illnesses susceptible of treatment with betablocker agents $(\mathrm{BB})$. In population studies, the prevalence of heart failure (HF) [2-9], coronary artery disease $[2-5,10-13]$ and arterial hypertension $[2,4,11,12]$, double those of the healthy control population and are usually higher than $20 \%$. In fact, at least one of these heart conditions is present in $25-35 \%$ of the patients with COPD [2, 5, 6, 11, 14]. Moreover, supraventricular arrhythmias -in some cases also susceptible to treatment with $\mathrm{BB}-$ are frequent in COPD as well $[2-4,15,16]$. Cardiovascular comorbidities occur even at the early

\footnotetext{
* Correspondence: Ipuente.hgugm@salud.madrid.org

'Servicio de Neumología, Hospital General Universitario Gregorio Marañón, c/Doctor Ezquerdo 46, Madrid 28007, Spain

${ }^{2}$ Instituto de Investigación Sanitaria Gregorio Marañón (liSGM), Madrid, Spain Full list of author information is available at the end of the article
}

stages of COPD, as it was shown in the Atherosclerosis Risk in Communities Study and the Cardiovascular Health Study, in which the risk of cardiovascular disease, hypertension and diabetes was already increased in patients with chronic bronchitis without pulmonary function abnormalities yet (Global Initiative for Chronic Obstructive Lung Disease stage 0) [11].

There is very strong, high quality, evidence demonstrating increased survival in patient with HF [16-19] and CAD [20] with BB therapy; nonetheless it is not unusual for physicians to consider COPD as contraindication to the use of BB [21] mainly because of concerns that they might induce bronchospasm and worsen lung function [22-25].

In this article, we will review the evidence for the benefits and safety of use of BB's in individuals with COPD and coexistent cardiovascular diseases.

\section{Review}

Impact of cardiovascular disease in copd outcomes Cardiac comorbidity has a substantial impact on the survival of COPD. In an observational study of 5648 
patients with COPD, cardiovascular morbidity and mortality was approximately two times higher than in historical controls without COPD [26]. The most common cause of cardiovascular morbidity and mortality was HF secondary to CAD [26]. In the towards a revolution in COPD health $\left(\mathrm{TORCH}^{\circ}\right)$ [ 26] study, heart diseases accounted for $27 \%$ of the deaths - second after respiratory processes [26] — which is a remarkable number considering that patients with known serious heart disease were excluded from the trial. In the Lung Health Study, a study of smoking intervention with medical advice and nicotine replacement therapy, in which more than 5900 patients with relatively mild COPD were followed for about 15 years, $30 \%$ of the deaths were due to either HF or CAD [27]. A retrospective study of the 11,493 COPD patients included in the health care databases maintained by the government of Saskatchewan, Canada during 1997-2000, reported one and half to four-fold increase in 3-year risk of cardiovascular death for different causes [overall relative risk (RR) for all cardiovascular causes $=2.1,95 \%$ confidence interval 1.8-2.4] compared with age- and sex-matched controls without COPD [3].

Cardiovascular events are common during exacerbations and are associated with increased risk of death. Troponin elevation takes place in a large number of patients (18-27\%) [28] undergoing COPD exacerbations requiring hospitalization [29-31]. This elevation is an independent predictor of mortality both during the exacerbation episode [29] and o,-term [30]. Ventricular arrhythmias and atrial fibrillation were independent predictors of mortality in a cohort of 580 patients having COPD as primary disease who were hospitalized in the respiratory unit of a university hospital from 1981 to 1990 [Odds ratio $(\mathrm{OR})=1.91$, $1.10-3.31$ and 2.27, 1.14-4.51, respectively] [32]. Several studies aimed to measure the incidence of left ventricular dysfunction in COPD exacerbations found a significant association between elevated brain natriuretic peptide or N-terminal fragment proNT-pro brain natriuretic peptide and increased cardiovascular mortality [33-36]

Cardiovascular disease also leads to hospitalization of COPD patients, left ventricular dysfunction may be present in more than $30 \%$ of acute dyspnea episodes in COPD patients attended at the emergency room or admitted to the hospital [33, 35-37]. In the Lung Health Study [27] cardiovascular causes accounted for $42 \%$ of first hospitalizations and $44 \%$ of second hospitalizations, while respiratory causes accounted for only $14 \%$ of admissions [27]. Raised troponin levels during an acute COPD exacerbation appears to increase the risk of further admissions $[34,36]$

\section{Impact of copd on cardiovascular diseases outcome}

From the cardiac perspective there is strong epidemiological evidence showing that the forced expiratory volume in the first second [38] $\left(\mathrm{FEV}_{1}\right)$ is a marker for cardiovascular mortality [39-45]. It has been estimated that for every $10 \%$ decrease in $\mathrm{FEV}_{1}$, cardiovascular mortality increases by $28 \%$ and non-fatal coronary events by almost $20 \%$ [39]. In the cohort of the Northern California Kaiser Permanente Medical Care Program $(n=45,966)$, COPD was an independent predictor of cardiovascular hospitalization and mortality over an average follow-up time of nearly 3 years [46]. In database of the Worcester Heart Failure Study (a populationbased investigation that includes residents of the Worcester, Massachusetts, metropolitan area) 9748 patients were hospitalized with acute decompensation of HF during the years 1995, 2000, 2002 and 2004. Among those who survived to hospital discharge, patients with COPD had a significantly higher risk of death along the next year than patients who had no previous diagnosis of COPD ( $R R=1.10,1.06-1.14)$ [47]. Among 4284 consecutive patients who underwent percutaneous coronary intervention in three tertiary medical centers in New York City between 1998 and 1999, 3-year mortality was $21 \%$ for patients diagnosed with COPD $(n=183$, $4.3 \%)$ versus $9 \%$ in those without COPD ( $<<0.001)$ [48]. Furthermore, with a hazard ratio $(\mathrm{HR})>2(\mathrm{HR}=$ $2.1,1.5-3.0, p<0.001)$, COPD was the strongest predictor of late mortality in the Cox proportionalhazard model after adjustment for demographic, clinical, and angiographic differences [48]. In one study of 860 patients with COPD and 10,048 without COPD of the National Heart Lung and Blood Institute, COPD was associated with higher mortality rates and repeat revascularization within 1 year after a percutaneous coronary intervention (HR 1.30, 1.01-1.67) [49]. Interestingly, in this study the higher proportion of adverse outcomes was associated with lower rates of use of BB [49].

\section{Beta-blockers}

Beta-adrenoceptors (B-ARs) are situated throughout the cardiac sarcolemma and bronchial and vascular smooth muscles $[50,51]$. While a majority of the B-ARs of myocardium are of the beta ${ }_{1}$ type $\left(\mathrm{B}_{1}\right.$-ARs), a considerable proportion $(20 \%-25 \%)$ are beta ${ }_{2}$-adrenoreceptos $\left(B_{2}\right.$-ARs) [50,51], however this quantity increases up to $40 \%$ in the failing heart [28], likely as result of the selective downregulation of $\mathrm{B}_{1}$-ARs observed in $\mathrm{HF}$ with little or no change in $\mathrm{B}_{2}$-ARs [28]. Both types of B-ARs of the myocardium, if activated, have a positive inotropic effect [50,51]. B-ARs in the bronchial and vascular smooth muscle are mostly $B_{2}$-ARs and when stimulated 
cause broncho- and vaso-dilatation [22, 24, 50, 51]. There is a third type of B-ARs (beta $a_{3}$, which role is not yet fully understood [52].

Beta-blockers are drugs capable of blocking B-ARs with little or no agonist effect and when administered reduce myocardial contractility at least in the short term [53]. Because of this, the use of $\mathrm{BB}$ was once thought to be contraindicated in patients with systolic dysfunction. Paradoxically, though, some BB's have proven striking morbidity and mortality benefits in the management of patients with cardiac diseases $[19,20,54-65]$ and currently they are considered standard therapy for hypertension, angina, post myocardial infarction, some tachyarrhythmias and congestive HF $[17,66]$.

BB's have several ancillary properties (i.e., partial agonism, cardioselectivity, membrane stabilizing effect, lipophilicity/ hydrophility, vasodilating actions and inverse antagonism) than need to be taken into account when selecting them for the treatment of heart diseases $[67,68]$. Some of them can be relevant when treating patients with COPD.

\section{Selectivity}

Beta-blockers are classified into three generations (Table 1) [50, 51, 60]. The first generation agents (such as propranolol, sotalol, timolol, and nadolol) are nonselective and block $B_{1}$-ARs and $B_{2}$-ARs. The second-

Table 1 Type of beta-blockers

\begin{tabular}{l} 
NON SELECTIVE \\
Intrinsic sympathomimetic activity \\
- Pindololol \\
• Oxeprenol \\
No intrinsic sympathomimetic activity \\
• Nadolol \\
- Propanololol \\
- Sotalol \\
- Timolol \\
CARIDOSELECTIVE \\
Intrinsic sympathomimetic activity \\
- Celiprolol \\
- Acebutolol \\
No intrinsic sympathomimetic activity \\
- Atenolol \\
• Bisoprolol \\
- Metoprolol \\
WITH ALPHA-BLOCKING ACTIVITY \\
• Carvedilol \\
- Labetolol \\
selective \\
\hline
\end{tabular}

generation agents are the cardio-selective agents (such as acebutolol, atenolol, bisoprolol, celiprolol, and metoprolol). The third generation agents have vasodilatory properties $[50,51]$ mediated either by nitric oxide release, i.e. nebivolol or carvedilol [52], by added alphaadrenergic blockade as in labetolol and carvedilol [52].

The blockage of $\mathrm{B}_{2}$-ARs can cause smooth muscle contraction and hence bronchospasm in predisposed individuals [50, 51]. Cardio-selective BB's have less impact on lung function and symptoms and preserve, in different magnitude, the bronchodilator effect of $\mathrm{B}_{2}$-ARs agonists (see below) $[50,51]$; however, it should be borne in mind that while cardio-selective $\mathrm{BB}$ mainly block $\mathrm{B}_{1}$ ARs, at high doses they are able to block $B_{2}$-ARs as well and can adversely affect the airways $[50,51]$. Therefore, the classification into 'cardio-selective' BB's and nonselective BB's is important, but oversimplified.

\section{Intrinsic sympathomimetic activity}

The therapeutic importance of intrinsic sympathomimetic activity (ISA) in COPD patients is questionable. Apparently, ISA is able to partially offset the increase in airway resistance that results from beta-blockade both at rest and during exertion [69], however no differences were observed among the non-selective BB's pindolol -an agent with ISA - and propranolol, oxprenolol and timolol - without ISA - in the reduction of $\mathrm{FEV}_{1}$ and the complete inhibition the bronchodilator response to inhaled isoprenaline [70]. On the contrary with the cardio-selective BB's atenolol and metoprolol the effect on $\mathrm{FEV}_{1}$ was less pronounced and some bronchodilator effect remained [70]. There is also evidence suggesting that BB's with ISA lead to a downregulation of $B_{2}$-ARs [71]. This finding is consistent with the observation that BB's with ISA do not produce the long-term increase in $\mathrm{B}_{2}$-agonist response seen with other BB's [51]. Since agents with ISA offer less cardio-protection than BB's without this property, these drugs are not recommendable in COPD patients with cardiac diseases.

\section{Inverse agonist activity}

BB's do not simply block the receptor, but may further inactivate receptor activity beyond its baseline value (i.e., they decrease the constitutive spontaneous activity of the receptor in the absence of agonist) [72]. This effect, called inverse agonist activity, is independent of the BAR selectivity and thus the of $B_{1}$-ARsselective metoprolol and bisoprolol have (modest) inverse activity $[53,67]$ as well as some non-selective BB such as timolol, propranolol or nadolol [53, 67], whereas carvedilol shows no inverse activity $[53,72]$.

Inverse agonist activity is important when B-ARs are downregulated because of chronic sympathetic activation, as occur in chronic HF $[51,53,73]$. In animal 
models of asthma, BB's with inverse agonist activity significantly increased B-ARs density in lung membranes [73] and with time were able to reverse the attenuation of the effect of salbutamol in airway relaxation induced by chronic HF [53]. These effects have been also documented in humans with mild asthma in whom chronic treatment with nadolol, a BB with Inverse agonist activity, enhanced the bronchodilator response to salbutamol over time [22].

\section{Safety of BB in COPD}

\section{Selective beta ${ }_{1}$ adrenergic blockade}

There are reports that in some predisposed patients BB, especially the non-selective ones, are able to trigger bronchospasm [74-78]; however several small studies of single-dose treatment or treatment for periods ranging from 2 days to 12 weeks provide prospective evidence demonstrating the short term safety of cardio-selective $\mathrm{BB}$ in COPD [79-81]. Long-term prospective evidence is scarcer. In one small study $(n=27)$ that examined the use of bisoprolol in patients with both HF and COPD a significant reduction in $\mathrm{FEV}_{1}$ was observed at 4 months ( $-70 \mathrm{vs}+120 \mathrm{ml}$ in the non-beta-blocker group $p<0.01$ ), however symptoms and quality of life were not altered [82]. Metoprolol was well tolerated for 3 months by 50 patients with coexistent CAD and mild to severe COPD. Patients remained free of adverse respiratory effects and $\mathrm{FEV}_{1}$ was unchanged [83]. In a randomized, doubleblind, crossover trial, 40 CAD patients with mild COPD and significant reversibility received either bisoprolol $5 \mathrm{mg}$ or atenolol $50 \mathrm{mg}$ [84]. $\mathrm{FEV}_{1}$ declined significantly ( $\sim .2 \mathrm{l})$ over 6 months in both treatment arms. Although lacking a concurrent placebo group, lung function parameters normalized during the placebo washout periods, suggesting beta-blockade could have caused bronchoconstriction [84].

Selective beta ${ }_{1}$-blockade does not attenuate the bronchodilation induced by beta ${ }_{2}$ agonists $[24,79,81,85]$.

\section{Non-selective BB combined with alpha-blockade}

The acute administration of labetalol at maximal dose did not affected $\mathrm{FEV}_{1}$ in 11 hypertensive patients with mild to moderate COPD $[86,60]$. In a retrospective analysis of the tolerance to carvedilol, 13 out of 89 patients with coexistent COPD and HF who received the drug for at least 3 months could not tolerate it [87]. The reasons for intolerance were not specified. Forty-three patients with HF and COPD with negative acute bronchodilator test receiving carvedilol were followed for a mean of 2.4 years and only 1 patient did not tolerate carvedilol because of COPD exacerbation [88]. In contrast, only $50 \%$ of 12 patients with asthma tolerated carvedilol [88] (Table 2). In one study of 63 (Table 2) elderly patients with mild to moderate HF and moderate to severe COPD, patients were randomized to bisprolol or carvedilol. While only in one patient of the carvedilol group the study medication had to be withdrawn because of wheezing, there were no differences between groups in the number of patients in which the BB had to be suspended (3 each) [89]. $\mathrm{FEV}_{1}$ significantly increased in bisoprolol $(\sim 130 \mathrm{ml})$ but not carvedilol $(\sim 30 \mathrm{ml})$ [89]. A randomized, open label, crossover trial involving 51 subjects receiving optimal therapy for HF (Table 2) examined the effects of switching baseline BB treatment to carvedilol, metoprolol or bisoprolol for 6 weeks before resuming their original $\mathrm{BB}$. Of the 51 subjects, thirty -five had coexistent mild to moderate COPD. In them $\mathrm{FEV}_{1}$ was lowest with carvedilol and highest with bisoprolol ( $150 \mathrm{ml}$ or $8 \%$ of difference). Response to salbutamol was tested in $53 \mathrm{HF}$ patients on background BB therapy and it was significantly higher in patients on bisoprolol as compared to carvedilol $(p=0.04)$ [90].

In summary the available evidence suggest that the third generation non-selective BB produce demonstrable changes in airway function in patients with COPD and tend to worsen airflow obstruction more than beta ${ }_{1}$ selective agents.

\section{Post-hoc analysis of prospective studies}

The analysis of COPD populations included in large studies on the use BB with HF [91, 92] show a protective effect comparing those on $\mathrm{BB}$ with those not using them [60].

\section{Cohort and administrative database studies}

Two meta-analysis of cohort studies have shown a protective effects of $\mathrm{BB}$ in patients with $\mathrm{COPD}$ and concomitant use of $\mathrm{BB}$ for $\mathrm{CAD}, \mathrm{HF}$ or other reasons $\mathrm{RR}$ $0.69(0.62-0.78)$ [93] and 0.72 (0.63 to 0.83 ) [94] respectively. A protective effect on the development of exacerbations was also observed in one of them [94]. Among 3834 residents of Alberta, Canada, aged 65 years or older, diagnosed with COPD who had at least one hospitalization for heart failure between April 1, 1994, and March 31, 1998 included in the Canadian Institute for Health Information database and followed a median of 21 month (Table 3), those on BB $(n=242)$ showed lower risk of all causes mortality $(\mathrm{HR}=0.78,0.63-0.95)$ [95]. In a cohort of 1966 patients (66 \pm 11 years) enrolled in general internal medicine clinics at seven Veterans Affairs medical centers between December 1996 and October 1999, Those who had a diagnosis of both COPD and hypertension and were receiving single-agent antihypertensive therapy were studied (Table 3). Compared with calcium channel blockers, BB were associated with a decrease in mortality from any cause after adjusting for other risk factors $(\mathrm{HR}=0.57,0.33-0.89)$. The association was similar when beta-blockers were compared 
Table 2 Clinical trials that have addressed the effect of beta-blockers on clinical of functional pulmonary outcomes in patients with concomitant cardiac and obstructive respiratory conditions

\begin{tabular}{|c|c|c|c|c|c|}
\hline & Population/design & $\mathrm{n}$ & Drug (mean daily dose) & $\begin{array}{l}\text { Follow- } \\
\text { up }\end{array}$ & Outcomes \\
\hline \multirow[t]{3}{*}{ Hawkins et al. [82] } & \multirow{3}{*}{$\begin{array}{l}\text { HF with moderate COPD/ } \\
\text { randomized, controlled, } \\
\text { double-blinded }\end{array}$} & \multirow[t]{3}{*}{$27(14 / 13)$} & \multirow[t]{3}{*}{$\begin{array}{l}\text { Bisoprolol }(7.3 \mathrm{mg}) \mathrm{vs} \\
\text { placebo }\end{array}$} & \multirow[t]{3}{*}{4 month } & $\begin{array}{l}\text { FEV }, \text { significantly decreased } \\
(-70 \text { vs. }+120 \mathrm{ml})\end{array}$ \\
\hline & & & & & SF- $36 \uparrow$ n.s. 2.6 vs 0.5 \\
\hline & & & & & No increase in exacerbations \\
\hline \multirow[t]{2}{*}{ Kotlyar et al. [88] } & \multirow{2}{*}{$\begin{array}{l}\text { HF with moderate COPD o } \\
\text { Asma/quasi-experimental }\end{array}$} & \multirow{2}{*}{$\begin{array}{l}\text { 31COPD/12 } \\
\text { Asthma }\end{array}$} & Carvedilol & \multirow[t]{2}{*}{2.4 year } & \multirow{2}{*}{$\begin{array}{l}\text { In } 1 \text { COPD ( } 3 \%) \text { and } 3 \text { asthmatics } \\
(25 \%) \text { the drug had to be withdraw } \\
\text { because of worsening of the respiratory } \\
\text { condition }\end{array}$} \\
\hline & & & $\begin{array}{l}\text { (29 mg COPD/19 mg } \\
\text { asthma) }\end{array}$ & & \\
\hline Lainscak et al. [89] & $\begin{array}{l}\text { Elderly HF with moderate } \\
\text { COPD/randomized, } \\
\text { controlled, open-label }\end{array}$ & $63(32 / 31)$ & $\begin{array}{l}\text { Bisoprolol }(47 \mathrm{mg}) \text { vs } \\
\text { Carvedilol }(6.4 \mathrm{mg})\end{array}$ & $\begin{array}{l}4-6 \\
\text { weeks }\end{array}$ & $\begin{array}{l}1 \text { patient of the carvedilol group had to } \\
\text { be withdrawn because of "wheezing", no } \\
\text { differences between groups in the number } \\
\text { of patients in which the BB had to be } \\
\text { suspended ( } 3 \text { each). FEV1 significantly } \\
\text { increased in bisoprolol ( } \sim 130 \mathrm{ml}) \text { but not } \\
\text { carvedilol ( } 30 \mathrm{ml})\end{array}$ \\
\hline $\begin{array}{l}\text { Jabbour et al. } \\
\text { [90]. }\end{array}$ & $\begin{array}{l}\text { HF with moderate COPD/ } \\
\text { randomized, open label, } \\
\text { triple-crossover }\end{array}$ & 35 & $\begin{array}{l}\text { Bisoprolol vs metoprolol vs } \\
\text { carvedilol equivalent dose } \\
\text { but mean not specified }\end{array}$ & 6 month & $\begin{array}{l}\text { FEV1 } 150 \mathrm{ml} \text { or } 8 \% \text { higher with bisoprolol } \\
\text { and metoprolol than with carvedilol }\end{array}$ \\
\hline \multirow[t]{2}{*}{ Camrari et al. [92] } & \multirow{2}{*}{$\begin{array}{l}\text { CAD with moderate to severe } \\
\text { COPD/quasi-experimental }\end{array}$} & \multirow[t]{2}{*}{50} & Metoprolol & \multirow[t]{2}{*}{3 month } & No change in $\mathrm{FEV}_{1}$ \\
\hline & & & $\begin{array}{l}(93 \mathrm{mg} \text { CR or } 189 \mathrm{mg} \\
\text { conventional) }\end{array}$ & & No adverse events \\
\hline \multirow[t]{2}{*}{ Dorow et al. [91] } & \multirow{2}{*}{$\begin{array}{l}\text { CAD with moderate COPD/ } \\
\text { randomized, double-blind } \\
\text { crossover }\end{array}$} & 40 & \multirow{2}{*}{$\begin{array}{l}\text { Atenolol (50 mg) vs } \\
\text { bisoprolol ( } 5 \mathrm{mg})\end{array}$} & \multirow[t]{2}{*}{6 month } & \multirow{2}{*}{$\begin{array}{l}\mathrm{FEV}_{1} \text { declined significantly }(\sim 0.2 \mathrm{l}) \text { in both } \\
\text { treatment arms. }\end{array}$} \\
\hline & & $(20 / 20)$ & & & \\
\hline
\end{tabular}

FEV ${ }_{1}$ forced expiratory volume in the first second; HF heart failure; CAD Coronary artery disease; COPD chonic obstructive lung disease; $n . s$. non-significant; SF-36; Shor form health survey questionnaire

with several other antihypertensive medications and was independent of whether the patient had a pre-existing cardiac disease [96]. The medical records of 41,814 COPD patients (22\% on BB) and 3819 asthmatics (17\% on $\mathrm{BB}$ ) with myocardial infarction were abstracted by the Cooperative Cardiovascular Project, which was sponsored by the Health Care Financing Administration for Medicare payment [20] (Table 3). BB treatment reduced the 2 -yr mortality $(\mathrm{OR}=0.60,0.57-0.63)$ similarly than in the non-COPD population [20]. A different analysis the same database included 54,962 with acute myocardial infarction as main discharge diagnosis and with COPD or asthma (defined by an established diagnosis previous to the admission or prescription respiratory medication in the medical records) (Table 3). Both respiratory conditions were pooled together for the analysis and patients were stratified according to severity based on the use of medication (yes or not $\geq 1$

Table 3 Association between beta-blockers and all-cause mortality in patients with chronic obstructive lung disease in observational studies

\begin{tabular}{lllll}
\hline & Population & n with COPD & Follow-up & Adjusted risk (95 \% Cl) \\
\hline Sin et al. [95] & Heart failure & 3834 & median 21 month & $0.78(0.63-0.95)$ \\
Hawkins et al. [91] & Heart failure & 1258 & median 25 month & $0.74(0.68-0.80)$ \\
Gottlieb et al. [20] & Myocardial infarction & 41,814 & 2 years & $0.60(0.57-0.63)$ \\
Chen et al. [97] & Myocardial infarction & 10,988 & 1 year & $0.86(0.73-1.00)$ \\
Van Gestel et al. [112] & Vascular disease & 1205 & median 5 years & $0.73(0.60-0.88)$ \\
Au et al. [96] & Hypertension & 1966 & 2 years & $0.57(0.33-0.89)$ \\
Rutten et al. [99] & COPD primary care & 2230 & 7.2 years & $0.68(0.56-0.83)$ \\
Lee at al. [102] & Multiple conditions & 1062 & median 44 months & $0.87(0.67-1.13)$ \\
Dransfield et al. [103] & COPD exacerbation & 825 & - & $0.39(0.14-0.99)$ \\
Stefan et al. [104] & COPD exacerbation & 10,174 & - & $088(0.71-1.09)$ \\
Short et al. [101] & COPD primary care & 5977 & 4.3 years & $0.78(0.67-0.92)$ \\
\hline
\end{tabular}


prescription of oral corticosteroids or $\geq 1$ admission the previous year). While $\mathrm{BB}$ showed a protective effect in those with mild/moderate COPD or asthma, no survival benefit (No harm either) was found with $\mathrm{BB}$ in the elderly and those with severe pulmonary disease [97]. As adherence to treatment was not available it is possible that those older or sicker could not take the $\mathrm{BB}$ as prescribed. In a retrospective observational cohort study 11,592 adult patients registered in the General Electric Centricity electronic medical record database with a diagnosis of asthma and/or COPD identified from August 1, 1997 to December 31, 2005 who were taking BB for at least 30 days were compared with patients who had never received BB (controls) (Table 3). Of these patients, 3062 were on cardio-selective and 690 on non-selective BB; 7840 were controls. While in patients with asthma, BB, particularly the non-selective ones, increased the risk of admission or visits to the emergency department,

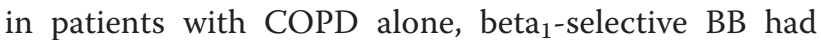
a protective effect for hospitalizations, $R R=0.64$ (0.43-0.96) while non-selective BB had not (RR 1.02, 0.52-2.02) [98]. In the Utrecht General Practitioners Network Database (Table 3), 2230 patients were identified who were older than 45 years with a diagnosis of COPD between 1996 and 2006. During a mean follow-up of $7.2(2.8)$ years, 686 patients (30.8 \%) died and $1055(47.3 \%)$ had at least 1 exacerbation of COPD. BB had a protective effect for both outcomes with adjusted hazard ratios of $0.68(0.56-0.83)$ and $0.71(0.60-0.83)$ respectively for mortality and exacerbations [99]. In a retrospective study of the Premier Perspective database involving 56,394 patients admitted with the diagnosis of COPD (Table 3), the allcause in-hospital mortality was $2.4 \%$. BB use had an independent protective effect on in-hospital mortality $(\mathrm{RR}=0.76,0.67-0.86)[100]$. In a recent retrospective cohort study in Scotland of 5996 COPD patients with concomitant CAD, HF or other vascular diseases, an overall $22 \%$ reduction in all-cause mortality was seen in those on $\mathrm{BB}$ therapy ( $88 \%$ of the $\mathrm{BB}$ used were cardio-selective) [101]. Furthermore, additive benefits to $\mathrm{BB}$ were observed with any of the possible combinations of inhaled therapy compared with controls (receiving only inhaled therapy with short acting bronchodilators) [101].

In partial contrast with the previous findings a recent study of the 2004-2007 Medicare Current Beneficiary Survey cohorts (a nationally representative sample of Medicare beneficiaries) including 1062 elderly patients (age $=77 \pm 7$ years) with COPD and CAD (half with and half without $\mathrm{BB}$ ), $\mathrm{BB}$ did not appear to have any protective effect on cardiac events, pulmonary events, or all-cause mortality (Table 3) [102]. In this study specific factors of older people such as functional and cognitive status were determinants of receiving $\mathrm{BB}$ and of experiencing the outcomes and may have influenced the results. In addition the sample size, while large, included much less patients than the other studies mentioned above and there is the possibility of a lack of statistical power to detect the protective effects of $\mathrm{BB}$. In any case it has to be stressed that no harmful effect on respiratory events was observed on the BB group.

\section{Exacerbations}

A relatively small retrospective study $(n=825)$ of the administrative data from the University of Alabama Hospital [60] suggested that BB use during exacerbations reduced mortality ( $\mathrm{OR}=0.39,0.14$ to 0.99$)$ [103] (Table 3). In a much larger retrospective cohort study $(n=35,082)$ of patients older than 40 years with CAD, CHF or hypertension, who were hospitalized for an acute exacerbation of COPD from the 1st of January, 2006 to the 1st of December, 2007 at 404 acute care hospitals throughout the USA, $29 \%$ were treated with $\mathrm{BB}$ in the first two hospital days, including $22 \%$ with beta $_{1}$-selective and $7 \%$ with non-selective BB (Table 3 ) [104]. There was no association between BB therapy and in-hospital mortality $(\mathrm{OR}=0.88,0.71-1.09)$, 30-day readmission $(\mathrm{OR}=0.96,0.89-1.03)$ or late mechanical ventilation $(\mathrm{OR}=0.98,0.77-1.24)$. However, when compared with beta ${ }_{1}$ selective $\mathrm{BB}$, receiving non-selective BB's was associated with an increased risk of 30-day readmission, $\mathrm{OR}=1.25$ (1.08 to 1.44$)$ [104].

In another study 8390 individuals with a diagnosis of asthma or COPD and receiving treatment with a $\mathrm{BB}$ or another cardiovascular agent were identified in 20002001 from three Veterans Administration databases in Iowa and Nebraska (USA) (Table 3) [105]. The HR for hospital admission for asthma or COPD during the observation year was not different for patients taking and not taking $\mathrm{BB}$ and no difference was noted with selective versus nonselective beta-blockers. Curiously enough, the hospital admission rate was lower with atenolol than metoprolol [105].

Considered together, the cumulative evidence from trials observational studies and meta-analysis indicates that selective beta ${ }_{1}$-blokers should not be withheld when COPD coexists with cardiovascular diseases, because the benefits for their cardiac conditions far outweigh the risks $[80,106]$. While cardio-selective agents cause less functional impairment, beta-blockade with both selective and non-selective agents, when required, beneficially impacts mortality [20, 93, 94, 97, 99, 101]. Therefore, current guidelines from the Heart Failure Society of America recommend $\mathrm{BB}$ in all patients with coexistent COPD and HF or CAD $[106,107]$. 


\section{Current use of BB}

In spite of the evidence in favor and guidelines recommendations [106-109], the proportion of COPD patients with indication for $\mathrm{BB}$ drugs because of a heart disease who are actually on BB remains low [103, 108, 110-113]. In one recent study in Spain BB were prescribe in around $58 \%$ of those COPD patients attended at specialized COPD clinics in whom $\mathrm{BB}$ were indicated, while in patients not believed to have COPD and managed by cardiologist the rate was $97 \%$. This proportion may be lower in the primary care settings [5]. While caution is needed when comparing information between different situations and different countries, it appears that there is a trend to increase the prescription of $\mathrm{BB}$ in COPD patients who need them for cardiovascular disease $[5,97,110,111,114]$; This is consistent with the trend to an increasing use of $\mathrm{BB}$ in COPD noticed in the Worcester (Massachusetts) Heart Attack Study cohort [115].

Some evidence suggests that to be effective in reducing admissions, BB therapy must adequately control heart rate (i.e. heart rate $<70 \mathrm{~min}^{-1}$ ) $[113,116]$.

The use of $\mathrm{BB}$ in patients with COPD and CHF can be substantially and safely increased by a structured outpatient program [117].

\section{Conclusions}

In summary, there is a bulk of evidence suggesting that $\mathrm{BB}$ therapy is safe in COPD patients who need it for coexistent cardiovascular diseases. Epidemiological evidence suggested that its use reduces mortality and the risk of exacerbations in general terms; Benefits are less evident in those older or with more severe disease.

Therapy should be attempted with selective beta ${ }_{-1}$ adrenergic blockade, but if necessary patients with concomitant stable mild to moderate COPD who do not have reversible airway obstruction can tolerate non-selective BB. Selective BB is recommended in patients with severe COPD or who have reversible airway obstruction. In these patients a close initial monitoring and management by physicians with experience is recommend.

Observational evidence suggests that BB therapy does not increase the risk of in-hospital mortality or late mechanical ventilation during exacerbations; therefore it is not necessary to routinely withdraw them during these episodes.

\footnotetext{
Abbreviations

B-AR: Beta adrenorecpetor; BB: Beta-blocker; CAD: Coronary artery disease; COPD: Chronic obstructive pulmonary disease; $\mathrm{FEV}_{1}$ : Forced expiratory volume in the first second; HF: Hearth failure; HR: Hazard ratio; ISA: Intrinsic sympathomimetic activity; OR: Odds ratio; RR: Relative risk; $95 \% \mathrm{Cl}$ : $95 \%$ confidence interval.
}

\section{Competing interests}

The authors declare that they do not have competing interests.

\section{Authors' contributions}

Luis Puente-Maestu: Redacted the draft manuscript and tables. Luis Antonio Álvarez-Salas Walther: Helped in the writing of the draft. Javier de Miguel Díez : Helped in the writing of the draft.All authors read and approved the final manuscript.

\section{Author details}

'Servicio de Neumología, Hospital General Universitario Gregorio Marañón, c/Doctor Ezquerdo 46, Madrid 28007, Spain. ${ }^{2}$ Instituto de Investigación Sanitaria Gregorio Marañón (liSGM), Madrid, Spain. ${ }^{3}$ Facultad de Medicina Universidad Complutense de Madrid (UCM), Madrid, Spain. ${ }^{4}$ Servicio de Medicina Interna Hospital General Universitario Gregorio Marañón, Madrid, Spain.

Received: 9 June 2015 Accepted: 6 November 2015

Published online: 25 November 2015

\section{References}

1. Raherison C, Girodet PO. Epidemiology of COPD. Eur Respir Rev. 2009;18: 213-21.

2. Cazzola M, Bettoncelli G, Sessa E, Cricelli C, Biscione G. Prevalence of comorbidities in patients with chronic obstructive pulmonary disease. Respiration. 2010;80:112-9.

3. Curkendall SM, DeLuise C, Jones JK, Lanes S, Stang MR, Goehring Jr E, et al. Cardiovascular disease in patients with chronic obstructive pulmonary disease, Saskatchewan Canada cardiovascular disease in COPD patients. Ann Epidemiol. 2006;16:63-70.

4. Feary JR, Rodrigues LC, Smith CJ, Hubbard RB, Gibson JE. Prevalence of major comorbidities in subjects with COPD and incidence of myocardial infarction and stroke: a comprehensive analysis using data from primary care. Thorax. 2010;65:956-62.

5. Hawkins NM, Jhund PS, Simpson CR, Petrie MC, Macdonald MR, Dunn FG, et al. Primary care burden and treatment of patients with heart failure and chronic obstructive pulmonary disease in Scotland. Eur J Heart Fail. 2010;12: 17-24.

6. Macchia A, Rodriguez Moncalvo JJ, Kleinert M, Comignani PD, Gimeno G, Arakaki D, et al. Unrecognised ventricular dysfunction in COPD. Eur Respir J. 2012;39:51-8.

7. Rutten FH, Cramer MJ, Grobbee DE, Sachs AP, Kirkels JH, Lammers JW, et al. Unrecognized heart failure in elderly patients with stable chronic obstructive pulmonary disease. Eur Heart J. 2005:26:1887-94.

8. Rutten FH, Moons KG, Cramer MJ, Grobbee DE, Zuithoff NP, Lammers JW, et al. Recognising heart failure in elderly patients with stable chronic obstructive pulmonary disease in primary care: cross sectional diagnostic study. BMJ. 2005;331:1379.

9. Soriano JB, Visick GT, Muellerova H, Payvandi N, Hansell AL. Patterns of comorbidities in newly diagnosed COPD and asthma in primary care. Chest. 2005;128:2099-107.

10. Tendera M, Fox K, Ferrari R, Ford I, Greenlaw N, Abergel $H$, et al. Inadequate heart rate control despite widespread use of beta-blockers in outpatients with stable CAD: findings from the international prospective CLARIFY registry. Int J Cardiol. 2014;176:119-24.

11. Mannino DM, Thorn D, Swensen A, Holguin F. Prevalence and outcomes of diabetes, hypertension and cardiovascular disease in COPD. Eur Respir J. 2008;32:962-9.

12. Marquis K, Maltais F, Duguay $V$, Bezeau AM, LeBlanc P, Jobin J, et al. The metabolic syndrome in patients with chronic obstructive pulmonary disease. J Cardiopulm Rehabil. 2005;25:226-32.

13. Soriano JB, Rigo F, Guerrero D, Yanez A, Forteza JF, Frontera G, et al. High prevalence of undiagnosed airflow limitation in patients with cardiovascular disease. Chest. 2010;137:333-40.

14. Nouwens E, van LJ, Wensing M. Comorbidity complicates cardiovascular treatment: is diabetes the exception? Neth J Med. 2012;70:298-305.

15. Shih HT, Webb CR, Conway WA, Peterson E, Tilley B, Goldstein S. Frequency and significance of cardiac arrhythmias in chronic obstructive lung disease. Chest. 1988;94:44-8. 
16. Buch $P$, Friberg J, Scharling $H$, Lange $P$, Prescott E. Reduced lung function and risk of atrial fibrillation in the Copenhagen City Heart Study. Eur Respir J. 2003;21:1012-6.

17. Packer M, Coats AJ, Fowler MB, Katus HA, Krum H, Mohacsi $P$, et al. Effect of carvedilol on survival in severe chronic heart failure. N Engl J Med. 2001;344: 1651-8.

18. The Cardiac Insufficiency Bisoprolol Study II (CIBIS-II): a randomised trial: Lancet 1999;353:9-13

19. Effect of metoprolol CR/XL in chronic heart failure: Metoprolol CR/XL Randomised Intervention Trial in Congestive Heart Failure (MERIT-HF): Lancet 1999:353:2001-2007.

20. Gottlieb SS, McCarter RJ, Vogel RA. Effect of beta-blockade on mortality among high-risk and low-risk patients after myocardial infarction. N Engl J Med. 1998;339:489-97.

21. Heller DA, Ahern FM, Kozak M. Changes in rates of beta-blocker use between 1994 and 1997 among elderly survivors of acute myocardial infarction. Am Heart J. 2000;140:663-71.

22. Hanania NA, Mannava B, Franklin AE, Lipworth BJ, Williamson PA, Garner WJ, et al. Response to salbutamol in patients with mild asthma treated with nadolol. Eur Respir J. 2010;36:963-5.

23. Matera MG, Calzetta L, Rinaldi B, Cazzola M. Treatment of COPD: moving beyond the lungs. Curr Opin Pharmacol. 2012;12:315-22.

24. van der Woude HJ, Zaagsma J, Postma DS, Winter TH, van HM, Aalbers R. Detrimental effects of betablockers in COPD: a concern for nonselective beta-blockers. Chest. 2005;127:818-24.

25. Salpeter SR, Ormiston TM, Salpeter EE. Cardiovascular effects of betaagonists in patients with asthma and COPD: a meta-analysis. Chest. 2004; 125:2309-21.

26. McGarvey LP, John M, Anderson JA, Zvarich M, Wise RA. Ascertainment of cause-specific mortality in COPD: operations of the TORCH Clinical Endpoint Committee. Thorax. 2007;62:411-5.

27. Anthonisen NR, Skeans MA, Wise RA, Manfreda J, Kanner RE, Connett JE. The effects of a smoking cessation intervention on 14.5-year mortality: a randomized clinical trial. Ann Intern Med. 2005;142:233-9.

28. Brodde OE. Beta 1- and beta 2-adrenoceptors in the human heart: properties, function, and alterations in chronic heart failure. Pharmacol Rev. 1991;43:203-42.

29. Baillard C, Boussarsar M, Fosse JP, Girou E, Le TP, Cracco C, et al. Cardiac troponin I in patients with severe exacerbation of chronic obstructive pulmonary disease. Intensive Care Med. 2003;29:584-9.

30. Brekke PH, Omland T, Holmedal SH, Smith P, Soyseth V. Troponin T elevation and long-term mortality after chronic obstructive pulmonary disease exacerbation. Eur Respir J. 2008;31:563-70.

31. Brekke PH, Omland T, Holmedal SH, Smith P, Soyseth V. Determinants of cardiac troponin T elevation in COPD exacerbation - a cross-sectional study. BMC Pulm Med. 2009;9:35.

32. Fuso L, Incalzi RA, Pistelli R, Muzzolon R, Valente S, Pagliari G, et al. Predicting mortality of patients hospitalized for acutely exacerbated chronic obstructive pulmonary disease. Am J Med. 1995;98:272-7.

33. Abroug F, Ouanes-Besbes L, Nciri N, Sellami N, Addad F, Hamda KB, et al. Association of left-heart dysfunction with severe exacerbation of chronic obstructive pulmonary disease: diagnostic performance of cardiac biomarkers. Am J Respir Crit Care Med. 2006;174:990-6.

34. Buchan A, Bennett R, Coad A, Barnes S, Russell R, Manuel AR. The role of cardiac biomarkers for predicting left ventricular dysfunction and cardiovascular mortality in acute exacerbations of COPD. Open Heart. 2015;2, e000052.

35. Ouanes I, Jalloul F, Ayed S, Dachraoui F, Ouanes-Besbes L, Fekih HM, et al. $\mathrm{N}$-terminal proB-type natriuretic peptide levels aid the diagnosis of left ventricular dysfunction in patients with severe acute exacerbations of chronic obstructive pulmonary disease and renal dysfunction. Respirology. 2012;17:660-6.

36. Marcun R, Sustic A, Brguljan PM, Kadivec S, Farkas J, Kosnik M, et al. Cardiac biomarkers predict outcome after hospitalisation for an acute exacerbation of chronic obstructive pulmonary disease. Int J Cardiol. 2012;161:156-9.

37. McCullough PA, Hollander JE, Nowak RM, Storrow AB, Duc P, Omland T, et al. Uncovering heart failure in patients with a history of pulmonary disease: rationale for the early use of B-type natriuretic peptide in the emergency department. Acad Emerg Med. 2003;10:198-204.

38. Metin G, Ozturk L, Duman ES, Demir T. Exercise duration rather than peak oxygen uptake better correlates with Fev1 and inspiratory capacity in chronic obstructive pulmonary disease. Arch Med Res. 2007;38:876-81.
39. Sin DD, Man SF. Chronic obstructive pulmonary disease as a risk factor for cardiovascular morbidity and mortality. Proc Am Thorac Soc. 2005;2:8-11.

40. Sorlie PD, Kannel WB, O'Connor G. Mortality associated with respiratory function and symptoms in advanced age. The Framingham Study. Am Rev Respir Dis. 1989;140:379-84

41. Ebi-Kryston KL, Hawthorne VM, Rose G, Shipley MJ, Gillis CR, Hole DJ, et al. Breathlessness, chronic bronchitis and reduced pulmonary function as predictors of cardiovascular disease mortality among men in England, Scotland and the United States. Int J Epidemiol. 1989;18:84-8.

42. Persson C, Bengtsson C, Lapidus L, Rybo E, Thiringer G, Wedel H. Peak expiratory flow and risk of cardiovascular disease and death. A 12-year follow-up of participants in the population study of women in Gothenburg, Sweden. Am J Epidemiol. 1986;124:942-8.

43. Truelsen $T$, Prescott $E$, Lange P, Schnohr P, Boysen G. Lung function and risk of fatal and non-fatal stroke. The Copenhagen City Heart Study. Int J Epidemiol. 2001;30:145-51.

44. Stavem K, Aaser E, Sandvik L, Bjornholt JV, Erikssen G, Thaulow E, et al. Lung function, smoking and mortality in a 26-year follow-up of healthy middleaged males. Eur Respir J. 2005;25:618-25.

45. Hole DJ, Watt GC, Davey-Smith G, Hart CL, Gillis CR, Hawthorne VM. Impaired lung function and mortality risk in men and women: findings from the Renfrew and Paisley prospective population study. BMJ. 1996;313:711-5.

46. Sidney S, Sorel M, Quesenberry Jr CP, DeLuise C, Lanes S, Eisner MD. COPD and incident cardiovascular disease hospitalizations and mortality: Kaiser Permanente Medical Care Program. Chest. 2005;128:2068-75.

47. Fisher KA, Stefan MS, Darling C, Lessard D, Goldberg RJ. Impact of COPD on the mortality and treatment of patients hospitalized with acute decompensated heart failure: the Worcester Heart Failure Study. Chest. 2015;147:637-45

48. Berger JS, Sanborn TA, Sherman W, Brown DL. Effect of chronic obstructive pulmonary disease on survival of patients with coronary heart disease having percutaneous coronary intervention. Am J Cardiol. 2004;94:649-51.

49. Enriquez JR, Parikh SV, Selzer F, Jacobs AK, Marroquin O, Mulukutla S, et al. Increased adverse events after percutaneous coronary intervention in patients with COPD: insights from the National Heart, Lung, and Blood Institute dynamic registry. Chest. 2011;140:604-10.

50. Albouaini K, Andron M, Alahmar A, Egred M. Beta-blockers use in patients with chronic obstructive pulmonary disease and concomitant cardiovascular conditions. Int J Chron Obstruct Pulmon Dis. 2007;2:535-40.

51. Matera MG, Martuscelli E, Cazzola M. Pharmacological modulation of betaadrenoceptor function in patients with coexisting chronic obstructive pulmonary disease and chronic heart failure. Pulm Pharmacol Ther. 2010;23: $1-8$.

52. Kalinowski L, Dobrucki LW, Szczepanska-Konkel M, Jankowski M, Martyniec L, Angielski S, et al. Third-generation beta-blockers stimulate nitric oxide release from endothelial cells through ATP efflux: a novel mechanism for antihypertensive action. Circulation. 2003;107:2747-52.

53. Rinaldi B, Capuano A, Gritti G, Donniacuo M, Scotto Di V, Sodano L, et al. Effects of chronic administration of beta-blockers on airway responsiveness in a murine model of heart failure. Pulm Pharmacol Ther. 2014;28:109-13.

54. Cardiovascular risk and risk factors in a randomized trial of treatment based on the beta-blocker oxprenolol: the International Prospective Primary Prevention Study in Hypertension (IPPPSH). The IPPPSH Collaborative Group: J Hypertens 1985;3:379-392

55. A randomized trial of beta-blockade in heart failure. The Cardiac Insufficiency Bisoprolol Study (CIBIS). CIBIS Investigators and Committees: Circulation 1994;90:1765-1773.

56. The sixth report of the Joint National Committee on prevention, detection, evaluation, and treatment of high blood pressure: Arch Intern Med 1997; 157:2413-2446.

57. Doughty RN, Rodgers A, Sharpe N, MacMahon S. Effects of beta-blocker therapy on mortality in patients with heart failure. A systematic overview of randomized controlled trials. Eur Heart J. 1997;18:560-5.

58. Freemantle N, Cleland J, Young P, Mason J, Harrison J. beta Blockade after myocardial infarction: systematic review and meta regression analysis. BMJ. 1999:318:1730-7

59. Frishman WH, Furberg CD, Friedewald WT. Beta-adrenergic blockade for survivors of acute myocardial infarction. N Engl J Med. 1984;310:830-7.

60. Heidenreich PA, McDonald KM, Hastie T, Fadel B, Hagan V, Lee BK, et al. Meta-analysis of trials comparing beta-blockers, calcium antagonists, and nitrates for stable angina. JAMA. 1999;281:1927-36. 
61. Lechat P, Packer M, Chalon S, Cucherat M, Arab T, Boissel JP. Clinical effects of beta-adrenergic blockade in chronic heart failure: a meta-analysis of double-blind, placebo-controlled, randomized trials. Circulation. 1998;98: 1184-91.

62. Mangano DT, Layug EL, Wallace A, Tateo I. Effect of atenolol on mortality and cardiovascular morbidity after noncardiac surgery. Multicenter Study of Perioperative Ischemia Research Group. N Engl J Med. 1996;335:1713-20.

63. Poldermans $\mathrm{D}$, Boersma $\mathrm{E}$, Bax JJ, Thomson IR, van de Ven $L L$, Blankensteijn $J \mathrm{D}$, et al. The effect of bisoprolol on perioperative mortality and myocardial infarction in high-risk patients undergoing vascular surgery. Dutch Echocardiographic Cardiac Risk Evaluation Applying Stress Echocardiography Study Group. N Engl J Med. 1999;341:1789-94.

64. Steinbeck G, Andresen D, Bach P, Haberl R, Oeff M, Hoffmann E, et al. A comparison of electrophysiologically guided antiarrhythmic drug therapy with beta-blocker therapy in patients with symptomatic, sustained ventricular tachyarrhythmias. N Engl J Med. 1992;327:987-92.

65. Wadworth AN, Murdoch D, Brogden RN. Atenolol. A reappraisal of its pharmacological properties and therapeutic use in cardiovascular disorders. Drugs. 1991;42:468-510.

66. Hjalmarson A, Goldstein S, Fagerberg B, Wedel H, Waagstein F, Kjekshus J, et al. Effects of controlled-release metoprolol on total mortality, hospitalizations, and well-being in patients with heart failure: the Metoprolol CR/XL Randomized Intervention Trial in congestive heart failure (MERIT-HF). MERIT-HF Study Group. JAMA. 2000;283:1295-302.

67. Khilnani G, Khilnani AK. Inverse agonism and its therapeutic significance. Indian J Pharmacol. 2011;43:492-501.

68. Bristow MR. What type of beta-blocker should be used to treat chronic heart failure? Circulation. 2000;102:484-6.

69. Taylor SH. Intrinsic sympathomimetic activity: clinical fact or fiction? Am J Cardiol. 1983;52:16D-26D.

70. Decalmer PB, Chatterjee SS, Cruickshank JM, Benson MK, Sterling GM. Betablockers and asthma. Br Heart J. 1978;40:184-9.

71. Sbirrazzuoli V, Drici M, Garraffo R, Candito M, Gibelin P, Morand P, et al. Changes in lymphocyte beta-adrenoceptor density after dilevalol oral treatment. Drugs Exp Clin Res. 1989;15:223-9.

72. Engelhardt S, Grimmer Y, Fan GH, Lohse MJ. Constitutive activity of the human beta(1)-adrenergic receptor in beta(1)-receptor transgenic mice. Mol Pharmacol. 2001;60:712-7.

73. Nguyen LP, Omoluabi O, Parra S, Frieske JM, Clement C, Ammar-Aouchiche Z, et al. Chronic exposure to beta-blockers attenuates inflammation and mucin content in a murine asthma model. Am J Respir Cell Mol Biol. 2008; 38:256-62.

74. Fraunfelder FT, Barker AF. Respiratory effects of timolol. N Engl J Med. 1984; $311: 1441$.

75. Tattersfield AE. Beta adrenoceptor antagonists and respiratory disease. J Cardiovasc Pharmacol. 1986;8 Suppl 4:S35-9. S35-S39.

76. O'Malley K, Cox JP, O'Brien E. Choice of drug treatment for elderly hypertensive patients. Am J Med. 1991;90:27S-33S.

77. Craig T, Richerson HB, Moeckli J. Problem drugs for the patient with asthma. Compr Ther. 1996;22:339-44.

78. Kendall MJ. Clinical relevance of pharmacokinetic differences between beta blockers. Am J Cardiol. 1997:80:15J-9J.

79. Salpeter S, Ormiston T, Salpeter E: Cardioselective beta-blockers for reversible airway disease. Cochrane Database Syst Rev 2002;CD002992.

80. Salpeter S, Ormiston T, Salpeter E: Cardioselective beta-blockers for chronic obstructive pulmonary disease. Cochrane Database Syst Rev 2005;CD003566.

81. Salpeter SR, Ormiston TM, Salpeter EE. Cardioselective beta-blockers in patients with reactive airway disease: a meta-analysis. Ann Intern Med. 2002; 137:715-25.

82. Hawkins NM, Macdonald MR, Petrie MC, Chalmers GW, Carter R, Dunn FG, et al. Bisoprolol in patients with heart failure and moderate to severe chronic obstructive pulmonary disease: a randomized controlled trial. Eur J Heart Fail. 2009;11:684-90.

83. Camsari A, Arikan S, Avan C, Kaya D, Pekdemir H, Cicek D, et al. Metoprolol, a beta-1 selective blocker, can be used safely in coronary artery disease patients with chronic obstructive pulmonary disease. Heart Vessels. 2003;18: 188-92.

84. Dorow $P$, Thalhofer $S$, Bethge $H$, Disselhoff $G$, Wagner $G$. Long-term treatment of angina pectoris with bisoprolol or atenolol in patients with chronic obstructive bronchitis: a randomized, double-blind crossover study. J Cardiovasc Pharmacol. 1990;16 Suppl 5:S36-44.
85. Salpeter S, Ormiston T, Salpeter E: Cardioselective beta-blocker use in patients with reversible airway disease. Cochrane Database Syst Rev 2001; CD002992.

86. George RB, Manocha K, Burford JG, Conrad SA, Kinasewitz GT. Effects of labetalol in hypertensive patients with chronic obstructive pulmonary disease. Chest. 1983:83:457-60.

87. Krum H, Ninio D, MacDonald P. Baseline predictors of tolerability to carvedilol in patients with chronic heart failure. Heart. 2000;84:615-9.

88. Kotlyar E, Keogh AM, Macdonald PS, Arnold RH, McCaffrey DJ, Glanville AR. Tolerability of carvedilol in patients with heart failure and concomitant chronic obstructive pulmonary disease or asthma. J Heart Lung Transplant. 2002;21:1290-5.

89. Lainscak M, Podbregar M, Kovacic D, Rozman J, von HS. Differences between bisoprolol and carvedilol in patients with chronic heart failure and chronic obstructive pulmonary disease: a randomized trial. Respir Med. 2011;105 Suppl 1:S44-9.

90. Jabbour A, Macdonald PS, Keogh AM, Kotlyar E, Mellemkjaer S, Coleman CF, et al. Differences between beta-blockers in patients with chronic heart failure and chronic obstructive pulmonary disease: a randomized crossover trial. J Am Coll Cardiol. 2010;55:1780-7.

91. Hawkins NM, Wang D, Petrie MC, Pfeffer MA, Swedberg K, Granger CB, et al. Baseline characteristics and outcomes of patients with heart failure receiving bronchodilators in the CHARM programme. Eur J Heart Failure. 2010;12:557-65.

92. Staszewsky L, Wong M, Masson S, Barlera S, Carretta E, Maggioni AP, et al. Clinical, neurohormonal, and inflammatory markers and overall prognostic role of chronic obstructive pulmonary disease in patients with heart failure: data from the Val-HeFT heart failure trial. J Card Fail. 2007;13:797-804.

93. Etminan M, Jafari S, Carleton B, FitzGerald JM. Beta-blocker use and COPD mortality: a systematic review and meta-analysis. BMC Pulm Med. 2012;12:48.

94. Du Q, Sun Y, Ding N, Lu L, Chen Y. Beta-blockers reduced the risk of mortality and exacerbation in patients with COPD: a meta-analysis of observational studies. PLoS One. 2014;9, e113048.

95. Sin DD, McAlister FA. The effects of beta-blockers on morbidity and mortality in a population-based cohort of 11,942 elderly patients with heart failure. Am J Med. 2002;113:650-6.

96. Au DH, Bryson CL, Fan VS, Udris EM, Curtis JR, McDonell MB, et al. Betablockers as single-agent therapy for hypertension and the risk of mortality among patients with chronic obstructive pulmonary disease. Am J Med. 2004;117:925-31

97. Chen J, Radford MJ, Wang Y, Marciniak TA, Krumholz HM. Effectiveness of beta-blocker therapy after acute myocardial infarction in elderly patients with chronic obstructive pulmonary disease or asthma. J Am Coll Cardiol. 2001;37:1950-6.

98. Brooks TW, Creekmore FM, Young DC, Asche CV, Oberg B, Samuelson WM. Rates of hospitalizations and emergency department visits in patients with asthma and chronic obstructive pulmonary disease taking beta-blockers. Pharmacotherapy. 2007;27:684-90.

99. Rutten FH, Zuithoff NP, Hak E, Grobbee DE, Hoes AW. Beta-blockers may reduce mortality and risk of exacerbations in patients with chronic obstructive pulmonary disease. Arch Intern Med. 2010;170:880-7.

100. Cheng Y, Borrego ME, Frost FJ, Petersen H, Raisch DW. Predictors for mortality in hospitalized patients with chronic obstructive pulmonary disease. Springerplus. 2014;3:359.

101. Short PM, Lipworth SI, Elder DH, Schembri S, Lipworth BJ. Effect of beta blockers in treatment of chronic obstructive pulmonary disease: a retrospective cohort study. BMJ. 2011;342:d2549.

102. Lee DS, Markwardt S, MCAvay GJ, Gross CP, Goeres LM, Han L, et al. Effect of beta-blockers on cardiac and pulmonary events and death in older adults with cardiovascular disease and chronic obstructive pulmonary disease. Med Care. 2014;52 Suppl 3:S45-51.

103. Dransfield MT, Rowe SM, Johnson JE, Bailey WC, Gerald LB. Use of beta blockers and the risk of death in hospitalised patients with acute exacerbations of COPD. Thorax. 2008;63:301-5.

104. Stefan MS, Rothberg MB, Priya A, Pekow PS, Au DH, Lindenauer PK. Association between betablocker therapy and outcomes in patients hospitalised with acute exacerbations of chronic obstructive lung disease with underlying ischaemic heart disease, heart failure or hypertension. Thorax. 2012;67:977-84.

105. Barnett MJ, Milavetz G, Kaboli PJ. beta-Blocker therapy in veterans with asthma or chronic obstructive pulmonary disease. Pharmacotherapy. 2005; 25:1550-9. 
106. Lindenfeld J, Albert NM, Boehmer JP, Collins SP, Ezekowitz JA, Givertz MM, et al. HFSA 2010 Comprehensive Heart Failure Practice Guideline. J Card Fail. 2010;16:e1-194.

107. Executive summary: HFSA 2006 Comprehensive Heart Failure Practice Guideline: J Card Fail 2006;12:10-38.

108. Global Initiative for Chronic Obstructive Lung Disease (GOLD) 2013: Global Strategy for the Diagnosis, Management and Prevention of COPD

109. Egred M, Shaw S, Mohammad B, Waitt P, Rodrigues E. Under-use of betablockers in patients with ischaemic heart disease and concomitant chronic obstructive pulmonary disease. QJM. 2005;98:493-7.

110. Behar S, Panosh A, Reicher-Reiss H, Zion M, Schlesinger Z, Goldbourt U. Prevalence and prognosis of chronic obstructive pulmonary disease among 5,839 consecutive patients with acute myocardial infarction. SPRINT Study Group. Am J Med. 1992;93:637-41.

111. Mentz RJ, Wojdyla D, Fiuzat M, Chiswell K, Fonarow GC, O'Connor CM. Association of beta-blocker use and selectivity with outcomes in patients with heart failure and chronic obstructive pulmonary disease (from OPTIMIZE-HF). Am J Cardiol. 2013;111:582-7.

112. van Gestel YR, Hoeks SE, Sin DD, Welten GM, Schouten O, Witteveen HJ, et al. Impact of cardioselective beta-blockers on mortality in patients with chronic obstructive pulmonary disease and atherosclerosis. Am J Respir Crit Care Med. 2008:178:695-700.

113. Andrikopoulos G, Pastromas S, Kartalis A, Toli K, Mantas I, Tzeis S, et al. Inadequate heart rate control is associated with worse quality of life in patients with coronary artery disease and chronic obstructive pulmonary disease. The RYTHMOS study. Hellenic J Cardiol. 2012;53:118-26.

114. van Gestel YR, Hoeks SE, Sin DD, Stam H, Mertens FW, Bax JJ, et al. Betablockers and health-related quality of life in patients with peripheral arterial disease and COPD. Int J Chron Obstruct Pulmon Dis. 2009;4:177-83.

115. Stefan MS, Bannuru RR, Lessard D, Gore JM, Lindenauer PK, Goldberg RJ. The impact of COPD on management and outcomes of patients hospitalized with acute myocardial infarction: a 10-year retrospective observational study. Chest. 2012;141:1441-8.

116. Puente-Maestu L, Calle M, Ortega-Gonzalez A, Fuster A, Gonzalez C, Marquez-Martin E, et al. Multicentric study on the beta-blocker use and relation with exacerbations in COPD. Respir Med. 2014;108:737-44.

117. Shelton RJ, Rigby AS, Cleland JG, Clark AL. Effect of a community heart failure clinic on uptake of beta blockers by patients with obstructive airways disease and heart failure. Heart. 2006:92:331-6.

\section{Submit your next manuscript to BioMed Central and take full advantage of:}

- Convenient online submission

- Thorough peer review

- No space constraints or color figure charges

- Immediate publication on acceptance

- Inclusion in PubMed, CAS, Scopus and Google Scholar

- Research which is freely available for redistribution

Submit your manuscript at www.biomedcentral.com/submit 